\title{
The Social History of Early Roman Coinage*
}

\author{
SETH BER NAR D
}

ABSTRACT

Fiscal explanations often given for Rome's first coins fail to account for the shape of monetary development. Nothing in the mid-republican budget matches the small scale and sporadic production of Roman coins during the early third century, or coinage's rapid expansion in the lead-up to the Second Punic War. Instead, I locate early Roman coinage within a broader reconfiguration of wealth and political power during the early phases of imperial expansion. Coins facilitated the exchange of wealth in the absence of strong social ties; conquest opened up Roman society to vast wealth of this order while also sparking debate about wealth's integration into the political community. Archaeological and textual evidence permits us to trace the contested and uneven development of elite accommodation to impersonal wealth during the third century. This context, I argue, offers the best explanation for Rome's initial coins.

Keywords: mid-republican Rome; Roman coinage; monetisation; money; economic sociology; Roman economy

Despite a very long history of study, it is my contention that we have not arrived at a satisfactory answer to the question of why Romans first used coins sometime around 300 B.c. ${ }^{1}$ The evidence presents several difficulties, including an apparent lack of correspondence between archaeology and textual sources and a scarcity of fixed points in the chronology. However, my critique is more methodological. By and large, scholarship has long sought a specific fiscal expenditure behind Rome's initial production of coinage. As I hope to make clear, nothing of this sort matches the character of Roman coinage in its earliest stages. The problem has been noted before, with some going so far as to deny the start of Roman coinage much significance, preferring instead to view the appearance of coins as a sort of economic non-event. ${ }^{2}$ If we hold, as I think we should, that Romans' initial use of coins marked a development of more than retrospective importance, then a new approach is needed.

One crucial, but under-appreciated, point is the extent to which the initial period of Roman coinage overlapped with radical transformations in Rome's society and economy. Recent syntheses of the mid-republican economy stress abundant change in the structure of land tenure and the scope of trade beginning around 300 B.C., but coins

\footnotetext{
* Earlier versions of this paper benefited from audiences at York University and McMaster University. I am particularly grateful to Ben Akrigg, Jonathan Edmondson, Amy Russell, James Tan, Kevin Wilkinson and the anonymous readers for $J R S$, all of whose valuable feedback has greatly improved my argument.

1 Scholarship starting with Eckhel is accessible through a series of reviews: Mattingly and Robinson I938; Thomsen I957-6I: I, 210-47; Vitale I999.

2 Cornell I995: 397 .
}

JRS Iо8 (2018), pp. I-26. (C) The Author(s) 2018.

Published by The Society for the Promotion of Roman Studies.

doi:IO.IOI 7/SOO754358I 8000497 
are not well integrated into this picture. ${ }^{3}$ Meanwhile, monetary history features little in accounts of the formation of the patricio-plebeian nobilitas or vice versa, even though Rome's political elite must ultimately have been responsible for deciding to produce coins. By overlooking the potential importance of such developments, scholarship tends in the Marxist sense to fetishise early Roman coins, approaching them in terms of their intrinsic character and utility, but with little regard for the social relationships for which they stand or the larger systems of value within which they operate.

This essay is therefore a deliberately wide-ranging attempt to understand Rome's first coins not as instrumental to any specific fiscal need, but rather as part of a shift in the way Romans constructed the relationship between wealth and political power. In other words, I suggest that the minting and use of coins in third-century Rome be understood as a social phenomenon. ${ }^{4}$ In doing so, I extend to the origins of Roman coinage an ongoing and welcome debate about the role of coins in Roman systems of value and exchange drawing from broader economic and anthropological theory. ${ }^{5}$

The literature produced by historians and anthropologists on the nature of money is vast. We may simply state that the use of coins, as any form of money, depends upon a socially constructed agreement concerning value. ${ }^{6}$ Such socialisation extends to consumers in the marketplace where parties were collectively required to accept coins' value. It also extends to minting authorities themselves. There was a multitude of non-monetary ways to mobilise resources on a vast scale, and this means that the decision to issue coins was contingent on the complexion of a state's political economy. (Already in the monarchic period and well before it struck coins, Rome fielded an army and built monumental architecture, points taken up below.) Thus, in all places and times where they appear money and coins are historically specific and should be analysed as such.

In approaching early Rome, it is important not only to consider the conditions that may have given rise to coinage, but also the continuing interaction between monetary and non-monetary systems of exchange. The general point is that few societies contain particular forms of economic exchange in isolation. There is, of course, a long pedigree to the idea that money replaced non-monetary exchange and arose in particular from frictions in barter economies. ${ }^{7}$ However, anthropologists are rightly critical of this view, as they point out that evidence for such putatively pure barter societies is non-existent, while barter features not uncommonly in societies that also know money. ${ }^{8}$ The early republican economy was not exceptional in this regard: while Roman jurists also thought that barter pre-existed money, monetised exchange featured in Roman society well before coinage and nearly as far back as the sources permit us to go. ${ }^{9}$ It is preferable to think therefore that Roman coinage emerged in a world of multiple ways of constructing and exchanging value. The complex interaction of different systems of exchange or 'transactional orders' is explored in particular by Parry and Bloch whose work has been influential on the study of archaic Greece but only starts to make inroads

\footnotetext{
3 cf. Morel 2007: 496-7; Panella 2010.

4 For the general view that social structure shapes economic actions and institutions, see Granovetter 2005 and 2017.

5 Aarts 2005; Verboven 2009; Von Reden 20I0; Howgego 20I3; Rowan 20I3; 20I6. Burnett and Molinari 20I 5: 96 suggest, but do not pursue, the approach for early Roman coinage.

6 Work on this subject includes, e.g., Zelizer I989; Ingham I996; Carruthers 2005.

7 Arist., Pol. I $257 \mathrm{a}$; Eth. Nic. II 33 ab; and much else besides. Modern attribution of money's origins to barter goes back to Adam Smith (I776) and continues to appear in monetary economics, see von Hagen 20 I 4.

8 Humphrey I985; Graeber 20II: 2I-4I.

9 For the Roman view that coinage arose out of barter, see Paul, Dig. I 8.I.I with Nicolet I984; status rather than the presence or absence of money seems to have held the most noticeable effects in differentiating early Roman exchange, see Viglietti 20I I: 245-56 on mancipatio and traditio.
} 
on the Roman side. ${ }^{10}$ They differentiate two timescales in which societies transact wealth. On one side is a longer-term order of exchange which serves to reproduce and maintain the prevailing social hierarchy; wealth is largely symbolic, and metal functions as a medium of aristocratic prestige and status. In Roman terms, this sphere would include the lavish gold and silver objects deposited in 'princely tombs' in Iron Age Latium. ${ }^{11}$ In opposition are short-term exchanges in which wealth is impersonal, liquid and accumulated rapidly from sources external to the aristocratic community such as markets, commerce, foreign trade, etc. The absence of strong social ties in such modes of exchange promotes quantifiable and standard forms of wealth that hold identical value both within and (especially) beyond individual communities or social networks. This quantification of value and its separation from social ties makes this short-term sphere the realm of money and coinage. ${ }^{12}$

Symbolic wealth supports aristocratic authority, but does not provide for a community's day-to-day functions, and so most if not all societies engage in the world of short-order exchange to some extent. ${ }^{13}$ Consequently, as Parry and Bloch observe, the regular interaction between transactional orders produces noticeable results. When the balance of individual wealth threatens the stability of longer-term aristocratic hierarchies, aristocracies often move to protect their monopoly on symbolic value by negatively portraying the short-term order as morally debased. Thus arise polemical attitudes towards money and foreign trade, which are attested widely throughout history. One might think of the paradox of the 'corrupting sea' across which regular interactions linking ancient Mediterranean communities were seen as both necessary and corrosive. ${ }^{14}$

Approaching coins as part of a particular but not exclusive system of exchange provides a way forward for understanding their appearance at Rome. More mechanically, I pursue the idea that coinage arose alongside acquisitive and market-oriented economic behaviours relating to the acquisition of wealth outside of existing Roman social networks; increased engagement in such activities dramatically shifted the balance of transactional orders and therefore stimulated a moralised discourse concerning wealth and aristocratic identity. I argue that precisely these trends were set in motion by the vast influx of foreign wealth from the initial phases of Roman imperial conquest, as well as by the related reconfiguration of the political order over the same time. Discussion starts with early Roman coins (Section I) and money (Section II), empirical features of which present difficulties for fiscal explanations for monetisation (Section III). Instead, I locate the appearance of coins within an evolving discourse over the ways in which certain forms of wealth supported political power from the early (Sections IV-V) to the later third century (Section VI). The conclusion reasserts coinage's importance for the social and economic history of mid-republican Rome (Section VII). Overall, my aim is not only to clarify the historical circumstances of the first appearance of Roman coins, but also to provide a model for future discussions of wealth and value in mid-republican society.

\footnotetext{
10 Parry and Bloch I989; for their influence on the study of Greece, see Von Reden I995; Kurke I999; Seaford 2004; for Rome, see especially Aarts 2005 and the discussion following his article. Parry and Bloch's model remains fundamental for anthropologists, see Maurer 2006: I 8; I disagree with the critique of Şaul 2005 that the model offers little more than a reformulation of Polanyi's views on money: while Polanyi described how different modes of exchange characterised societies, Parry and Bloch focus on the interaction between such modes within single societies.

11 Colonna I988: 468 .

12 While I focus on coins' expediency to market exchange, they also function in symbolic transactions. Mid-republican coinage, for example, was regularly used as votives in sanctuaries, see Crawford 2003; Molinari 2004; Gorini 20I I; generally, Aarts 2005.

13 cf. Bresson I987 on foreign trade and the autarkic polis.

14 Horden and Purcell 2000.
} 
The argument against a fiscal explanation for early Roman coinage depends not only on a more sociological approach, but also on the technicalities of the coins themselves. The most striking aspects of pre-denarius Roman coin production are its irregularity and small scale, features which persisted for a long time after the initial issues. ${ }^{15}$ By this point, the chronology has been discussed in almost every point of detail, and the following brief review intends mostly to account for some recently published material. ${ }^{16}$

The first 'Roman' coin, a struck bronze litra with Greek legend POMAISN $\left(R R C_{\mathrm{I}} / \mathrm{I}^{17}\right)$, was likely minted at Naples after the foedus Neapolitanum of 326 B.C. Several decades later, the first of four heavy silver didrachms with Latin legend ROMANO $\left(R R C_{\mathrm{I} 3 / \mathrm{I}}\right)$ was struck depicting Mars and a horse's head, perhaps also in Naples and with a silver fraction and perhaps another in bronze. ${ }^{18}$ On the evidence of hoards, this didrachm is normally dated to either slightly before or slightly after 300 B.C. The coin must antedate 273 B.C., since an example has been found at Poseidonia/Paestum in stratigraphic layers cut into by the construction of the wall of the Latin colony founded at that date. ${ }^{19}$ The second silver didrachm with Apollo/horse (RRC I 5/I) followed a cessation of minting activity of some time. For this coin's date, we rely on the important hoard from San Martino in Pensilis, which contains three examples of $R R C \mathrm{I}_{3} / \mathrm{I}$ in worn condition and five fresh examples of $R R C \mathrm{I}_{5} / \mathrm{I}$, some displaying linked dies. ${ }^{20}$ The hoard's deposition is dated by Italian silver issues to c. 250 B.C., and the Apollo didrachm should date shortly prior, perhaps as late as c. 260 B.C. The third Hercules/ wolf-and-twins didrachm $(R R C 20 / \mathrm{I})$ circulated with late Neapolitan didrachms and Campano-Tarentine didrachms, which are dated by related overstrikes to the late 2605 or 250 s. $^{21}$ The fourth and lightest Roma/Victory ROMANO didrachm (RRC 22/I) followed.

At some point and for reasons not entirely clear, legends on Rome's struck coinage change from ROMANO to ROMA. The latter legend features on the reverse of three lighter didrachms and related bronzes. ${ }^{22}$ Recent study suggests the change in legends came quite late. Burnett and McCabe identify the prototype of the eagle on the reverse of the large format ROMANO bronze with the head of a goddess on its obverse ( $R R C$ $23 / \mathrm{I}$ ) as the bird found on a Ptolemaic octobol issued under Ptolemy III Euergetes after 245 B.C. The Roman coin must post-date its prototype placing this issue of the ROMANO series no earlier than the last years of the First Punic War. ${ }^{23}$ This date converges with the evidence of a newly discovered hoard from Nora in Sardinia, which

\footnotetext{
15 Following Thomsen I957-6I and Crawford I974, the orthodox chronology was established by Mitchell I966 and especially Burnett I977 on the basis of hoards; recent summaries in Rutter 200I; Burnett 20I2. For discontinuity, see Burnett I998: 36 and 2012: 310. Mattingly I99I takes issue with Burnett's gap of around forty years between the first two silver strikes; his date of $c .280$ B.c. for $R R C_{I_{3} / I}$, while not impossible, still leaves considerable time between emissions.

16 The most useful evidence remains numismatic and archaeological. Debate over iconography is lively but inconclusive, as noted by Woytek 20I4: 205-6; for this approach, see Burnett I986; Hollstein I998-9; Coarelli 20I3.

17 Coin types are indicated with reference to $R R C=$ Crawford 1974 .

18 For the bronze RRC 2/I, see below, Section III.

19 Rouveret and Theodorescu 2000: I94-6; this all but excludes a dating of 275 B.C. by Pedroni I993, but does not necessarily affirm a late fourth-century date, contra Burnett and Crawford 20I4: 237 n. II.

20 Burnett 2006; Coarelli 2013: 39-40 dismisses the different conditions of the coins too lightly.

21 Burnett and Crawford I998.

22 The correspondence between weight reduction and changing legends in the silver issues, as well as hoard evidence, rules out the idea that coins with ROMANO and ROMA legends were struck simultaneously; cf. Rutter 200I: 45. It is often suggested that the change relates to a move in the minting location to Rome, as e.g. Pedroni I993: 46; this is logical, but not easy to reconcile with other evidence.

${ }_{23}$ Burnett and McCabe 2016 prefer a date for the Ptolemaic prototype of $c$. 240-220 B.C., putting the Roman
} 
contains freshly minted examples of several ROMA silvers, some displaying linked dies. ${ }^{24}$ The Nora hoard dates the production of the ROMA coins to the 230 since its deposition must postdate Rome's establishment of control over Sardinia in 238 B.C.

Thus, the shift from ROMANO to ROMA legends does not appear to have taken place until at least a half century after the minting of the first silver didrachm. This date makes Rome's initial coinage seem sporadic with seven series of Romano-Campanian silver coins struck on an average of about one series per decade from c. 300 to c. 230 B.C. Perhaps these dates might be moved around somewhat. The San Martino in Pensilis hoard makes Rome's initial silver didrachm appear less isolated in relation to the second didrachm than had previously been thought. ${ }^{25}$ Meanwhile, Fischer-Bossert's restudy of Tarentine silver didrachms with which Rome's first didrachms frequently circulate also allows for a down-dating to $c .280$ B.C. of several contexts that include $R R C \mathrm{I}_{3} / \mathrm{I} .{ }^{26}$ However, we cannot now go beyond the two aforementioned fixed points: (i) the Poseidonia/Paestum example of $R R C \mathrm{I}_{3} / \mathrm{I}$, which affirms the first silver issue's date prior to 273 B.C., and (ii) the down-dating of $R R C 23$ / I to after its Ptolemaic prototype of c. 245 B.C., with the minting of the ROMA legend coins afterwards. Even if we compress the coinage within these limits as far as possible, Romano-Campanian coinage appears intermittent through the First Punic War. Dies indicate moreover that these strikes were small in scale, and the physical characteristics of particularly the ROMANO didrachms vary. There is thus no reason to postulate an even chronological spread or consistent minting circumstances within this timeframe.

Production technique among other factors makes it harder to provide a similarly detailed discussion of the early cast bronze; without the help of die studies, and with no surviving aes grave mould, it is hard to draw conclusions about the scale of these issues. The earliest series also follow a somewhat unusual weight progression, with the second issue cast on a heavier libral as than the first, before a series of reductions starting in the mid-third century. A strict metrological connection between these initial libral and supra-libral aes grave and the Romano-Campanian struck coinage is no longer regularly accepted. ${ }^{27}$ Instead, current opinion holds that the aes grave started independently just before the First Punic War. The date is indicated by the appearance of coin types stamped onto black-gloss ware forms of $280-260$ B.C., as well as by hoards of these coins recently found in foundation deposits in the coastal sanctuary of Sol Indiges at Lavinium. $^{28}$

What can be said, and what makes the cast bronze coinage remarkable, is the broad range of its denominational structure even in the earliest libral issue. These coins came in a variety of units from the large and physically cumbersome as to up to six standard sub-denominations including very small fractions. While it is difficult to ascertain the real value of these cast coins, the libral weight of the as suggests they were not fiduciary. ${ }^{29}$ If we may infer from a passage in the Twelve Tables that a libra was around this time conceived of as equivalent to a minimum daily allowance of grain, then the smallest fraction, a semuncia ( $\mathrm{I} / 24$ of a libra), was of miniscule value. ${ }^{30}$ The implication

issue after the First Punic War. The possibility remains that the Ptolemaic bronze was struck earlier in Ptolemy III's reign, which began in 246 B.C.

24 Gorini 2016.

25 No hoard containing both coins was known to Burnett I977.

26 Fischer-Bossert I999: 347.

27 cf. Lo Cascio I980-I; Marchetti I993: 44; a connection emerges with the ROMA coinage, see Burnett I998: 32; Rutter 200I: 45.

28 Jaia and Molinari 20 II.

29 The coinage was in fact a hybrid with some low denominations being fiduciary, as uncia and semuncia were sometimes identical in weight and size but displayed different marks of value.

30 Table III.4 (ed. Crawford). 
is both that of small change and of attention to a very wide range of transactions from the outset of Roman coin production. Such denominational variety challenges the idea that coins were intended to meet any single state-level need, as Kim similarly suggests for fractional coinage in archaic Greece, and I return to this argument below. ${ }^{31}$

The picture of sporadically issued coinage throughout most of the third century is challenged by Coarelli, who revives Böckh's idea that the quadrigatus was the 'argentum signatum' identified by Pliny $(H N$ 33.44) as first struck at Rome in 269 B.C. He therefore suggests that quadrigati were continuously minted from that point down to the early years of the Second Punic War. ${ }^{32}$ The evidence, however, offers little support to either the early date or the idea of extended production. Quadrigati are absent from all mid-third-century hoards, including the aforementioned Nora hoard, which otherwise provides a full snapshot of Roman circulation after 238 B.C. Recent die study of the quadrigatus coinage demonstrates that this issue, while quite large, divides into only a few groups, which implies a compressed minting period, rather than a long serial emission. Furthermore, the geographical distribution of hoards containing quadrigati coheres well with military activity during the Second Punic War, and Debernardi and Legrand reasonably date the first quadrigati to the years around the fall of Saguntum. ${ }^{33}$

The late appearance and compressed production of the quadrigatus are crucially important, because these coins were produced on a dramatically larger scale than any earlier Roman issue. ${ }^{34}$ While the inability to count dies makes similar comparisons difficult for the aes grave, there are more extant examples of the heavy prow bronzes $(R R C 35)$, linked iconographically with the quadrigati, than previous coins, and on that basis they seem to have been a larger issue. ${ }^{35}$ The considerable increase in silver coin in the last quarter of the third century may then have been reflected across the entire monetary system.

In sum, any interpretive model of the appearance of coins at Rome must contend with three features: first, the initial production of coins with Roman legends in the late fourth and early third centuries; second, the fact that production remained limited for almost a century after these issues; and third, the rapid expansion of coin production in the lead-up to the Second Punic War.

One explanation for the initially small scale of early Roman coin production that must be excluded is that Romans were simply unaware, or only slowly became aware, of metal's potential monetary function. It would be wrong to say that pre-coinage Roman society was un-monetised. While silver was generally scarce, archaic Rome like most central Italian societies used bronze for a unit of account from an early point. ${ }^{36}$ While Rome has no native metal resources, signs of metallurgy appear in the city's archaeological record as early as the late Bronze Age. ${ }^{37}$ Romans themselves believed that important

\footnotetext{
31 Kim 200I.

32 Coarelli 2013; Böckh I834; see also Lo Cascio I980-I; Marchetti I993; Debaes 2007. For more extensive rebuttal of Coarelli, see Burnett and Crawford 2014; Bernard 2017.

33 Debernardi and Legrand 20I4: 225-8. As the authors note, two much-debated hoards from Selinunte, destroyed by Carthage in 250 B.C., cannot independently overturn this judgement.

34 Compare die counts in Burnett I989:42-3 to those in Debernardi and Legrand 20I4: 2I 2-I3; the issue was also highly complex with multiple fractions including a silver oath-scene drachm only identified in 2007; see Debernardi and Legrand 2015.

35 Burnett I989: 45 n. 63 .

36 Crawford I976; I985; Peruzzi 1985; Catalli 2001. On credit and debt in the pre-coinage economy, see Gabrielli 2003; LeRouxel 2015; Bernard 2016.

37 Giardino and Lugli 2001.
} 
steps towards the use of metal as money occurred during the monarchic period and early Republic. Some sources are clearly anachronistic in this regard: Calpurnius Piso reported that Tarquinius Superbus spent 40,000 talents of silver on the Capitolium's construction. ${ }^{38}$ However, more credence might be given to reports of fines assessed in bronze asses during the fifth century, or to the Twelve Tables' references to bronze as a unit of account. ${ }^{39}$ LeRouxel is correct to emphasise commerce's role in the archaic economy, but it need not follow that bronze itself was used as a form of currency by that point, nor does the material evidence suggest as much; metal in the form of lumps of ferrous bronze (aes rude) are not known to display anything resembling a consistent weight standard. ${ }^{40}$

Along with a standard of value, metal also probably functioned from an early point as a means of storing wealth. This was the case in the Greek world including South Italy, where bullion appeared well before coinage, most frequently in temples and sanctuaries. ${ }^{41} \mathrm{~A}$ possible central Italian parallel appears in the cast bronze ingots with dry branch patterns, the so-called ramo secco bars, the majority of which are found in relation to cult sites.

While the ramo secco bars represent the earliest cast bronze ingots regularly produced in central and northern Italy, their importance to Rome's own monetary history has been overstated. No example is known from Rome itself and comparatively few are documented from Latium. It was once proposed that a hoard found at the sanctuary at Bitalemi near Gela in Sicily containing a fragmentary ramo secco bar along with a considerable amount of aes rude confirmed an early transitional moment from unformed to formed bronze in the sixth century; this date, it was noted, was roughly contemporary with King Servius, whom Pliny and others credited with such an advance (see below). However, iconographic and, especially, petrochemical study now demonstrates the Bitalemi ramo secco fragment's affinity with other bars of the late fifth century and all but confirms that later date. ${ }^{42}$ This should end once and for all discussion of a link between ramo secco and Servius. What the Bitalemi hoard shows instead is that the circulation of ramo secco bars did not cause the phasing out of aes rude in Italy. Indeed, aes rude outlived ramo secco bars and continued to appear in hoards of Roman aes grave. ${ }^{43}$ The monetary systems each represented were by no means exclusive, and new practices did not displace conservative ones. Instead different forms of metallic wealth circulated together well into the early period of coinage.

The historical record complements the understanding of these trends by suggesting that the Roman state was actively rethinking monetary issues such as liquidity and exchange well before the production of coinage. Important is Livy's account of a panel of five 'bankers' ('quinqueuiri mensarii') established in 352 B.C. to address problematic private debts (7.2I.5-8). By offering fair-market valuations of property, these bankers cleared a large number of outstanding loans, although with mixed success, since the censors in 350 B.C. found confusion had arisen over properties that had recently changed hands. If authentic, the episode shows interest on Rome's part in addressing a problem of liquidity rather than insolvency since, according to Livy, the repayment of debts was hindered 'more by the sluggishness of the debtors than by their finances' ${ }^{44}$

Over the next decades, further hints appear of Roman interest in liquidity and the exchange of wealth, including in metallic form. The legal manipulation of interest rates

\footnotetext{
8 L. Calpurnius Piso FI9 (FRHist) = Livy I.55.9.

Crawford I985: I7-24.

LeRouxel 20I 5: I I9-2I; on early Roman commerce, see Viglietti 20 I I.

Kroll 2008.

2 Pellegrini and Macellari 2002.

3 See the list in Jaia and Molinari 20I I: 95-7.

44 Storchi Marino I993; Bernard 2016: 329-30.
} 
in 357 and 342 B.C. may, as Zehnacker argues, ${ }^{45}$ point to the increased monetisation of debt, which was previously more closely tied to the agricultural cycle. The installation of stalls (tabernae) for argentarii in the forum also plausibly fits a pattern of increasing monetary thought, since later argentarii engaged in money-changing. Such tabernae are first mentioned in 309 B.C. in relation to their receipt of gold and silver armour taken from the Samnites (Liv. 9.40.I6). Coarelli connects their construction with C. Maenius' censorship in 3 I 8 B.C., putting the appearance of the argentarii before Roman silver coinage. ${ }^{46}$ Their occupational title obviously relates to silver (argentum), but since there is little evidence of even foreign silver coinage at Rome from this time, debate arises over their initial function and potential anachronism. ${ }^{47} \mathrm{I}$ am inclined to follow Andreau in identifying them as bankers, rather than silversmiths; however, it seems unnecessary to define their initial function too rigidly as their duties may have pertained to the range of uses of precious metals at Rome at that time. From these figures back to those earlier uses of bronze in the archaic economy, it is enough to note several indications that Rome's first coins formed part of a much longer trajectory of Roman monetisation. ${ }^{48}$

III

Various explanations put forward for early Roman coinage must be evaluated in light of both Rome's long monetary history and coinage's initially sporadic nature. Large costs such as war-making and public works often associated with coin production do not align well with the Roman evidence. ${ }^{49}$ Rome paid soldiers stipendium for perhaps a century before coinage, while there were no more than four peaceful years between 326 and 24I B.C. The scale of fighting may have increased, but it would be difficult to match such increases to coin production prior to the Second Punic War, and this makes a strict connection between military expenditure and small-scale, intermittent coinage unlikely. Some have sought an explanation in a component cost of warfare such as mercenaries; however, while frequent in Magna Graecia, mercenaries are almost never attested in the mid-republican army. ${ }^{50}$ A link between naval warfare and coinage, well established for classical Athens, ${ }^{51}$ has likewise been suggested. While mid-republican Rome increasingly involved itself in maritime warfare over the third century, the literary evidence for naval finance is far from straightforward, even when speaking of the largest fleets of the period: again, the issue of monetisation is hard to explain as a simple matter of Rome's reaching a threshold in any activity's scale or cost. ${ }^{52}$ The thirty ships with which Scipio invaded Africa in 204 B.C., for example, were built and supplied not at public expense, but from materials donated by allied cities in Etruria. ${ }^{53}$ Earlier in the war, Scipio enslaved the craftsmen of New Carthage as rowers in his fleet. ${ }^{54}$ This is not to suggest that coinage was unimportant to Roman conquest; however, Roman imperial power

45 Zehnacker I980.

46 Coarelli I985.

47 Crawford I985: I7 n. 2 argues for silversmiths; Andreau I987: 337-40 suggests bankers. Coin circulation in mid-republican Rome is summarised in Burnett and Molinari 201 5: 92.

48 Similarly for archaic Greece, see Kroll 2008.

49 e.g. Grierson I977: 5; for a wider view on the impulse to coin, see Howgego I990; debate over state interest in consumer liquidity provoked by Lo Cascio I98 I may be more relevant to the earlier situation than acknowledged.

50 Rosenstein 2004: 39; Bourdin 2012: 56I-2; for mercenaries and coinage in the post-Alexandrian western

Mediterranean, see Williams and Burnett I998; Termeer 2016.

51 Van Wees 20I3.

52 For what it is worth, ancient sources interpreted prows on coins as anything but naval: Ov., Fast. I.23 I-40;

Plut., Quaest. Rom. 4I.

53 Livy 28.45.I5.

54 Polyb. I0.I 7.9; Livy 26.47.I. 
was expressed in different forms, not all of them monetised, and a strict connection between coins and military operations in the early period cannot be assumed uncritically.

In terms of public construction, the Roman state built on a large scale well before it made coins, and this fact raises similar problems in correlating building to coinage. Undoubtedly, Rome's construction industry was active around 300 B.C., while Polybius cited infrastructural costs as the Senate's largest expense (6.I3.3). Appius Claudius Caecus' road and aqueduct begun in 3 I 2 B.C. were ambitious and implied sizeable costs, and the association of the first silver didrachm $\left(R R C \mathrm{I}_{3} / \mathrm{I}\right)$ with the Via Appia consequently finds some following. ${ }^{55}$ For technical reasons discussed above, it seems unlikely to me that this issue dates so early. More fundamentally, coins were by no means necessary for monumental building at Rome or in other pre-modern states. Sources relate the use of forced labour by the Tarquins for their grand building programme and by the censors of 378 B.C. for building the massive fortification walls. ${ }^{56}$ Whether or not we follow all the details concerning the organisation of these building projects, there is no denying that monumental Roman architecture was built on a very large scale without coins, and the idea that big building projects required monetary innovation is unfounded.

Against the idea of outsized state costs, the inclusion of fractional coinage and the remarkable denominational variety of the aes grave suggest that Rome's first coins were a medium for transactions of widely varying size and type. This problematises some recent attempts to attribute coins to particular payments beyond military pay or public construction. Humm sets out a complex argument for associating the first Roman didrachm with nummi paid by Capuans to newly enfranchised Campanian equites in the late fourth century. ${ }^{57}$ However, it is not clear why a lump sum would have required both a didrachm and a fractional silver unit worth $\mathrm{I}_{\mathrm{I} 2} 2$ its value $\left(R R C_{\mathrm{I}} / 2 / 2\right) .{ }^{58}$ If the enigmatic struck bronze issue $R R C 2 / \mathrm{I}$ is also a fraction of the first didrachm, as recently suggested, this complicates things even further. ${ }^{59}$ We would also still need to explain why coinage was deemed convenient for this purpose but was not more expansively adopted for some time.

Alternatively, Burnett, who has long resisted budgetary explanations for early Roman coinage, suggests that monetisation was essentially a form of Hellenisation. ${ }^{60}$ That is, once Rome came into contact with Greek monetary systems, it adopted coins just as Roman cultural production otherwise took on characteristics of Greek art, architecture or literature. While this is an important thesis since it moves beyond fiscal approaches, it does not necessarily offer a more complete explanation for the shape of early Roman coin production. Rome's cultural contacts with the Greek East were established from a very early point, so it remains to be explained why Greek cultural practice prompted coinage when it did. Even if, as some suggest, the late fourth and early third centuries were a particularly intense moment of Hellenisation at Rome, this still would not explain why coins were produced intermittently for several decades.

Moreover, as often noted, the concept of Hellenisation tends to flatten the complexities of Greek practices while denying agency to those adopting such practices. It does, however, become useful to look at the particular avenues by which Greek cultural practices came to be adopted at mid-republican Rome. For Romans as for others, Greek cultural elements

\footnotetext{
55 Crawford I985: 29; Cornell I995: 396; Laurence I999: I 5-I6.

56 For the scale of sixth-century building at Rome, see Hopkins 2016; for sources, Milazzo I993; cf. Livy 6.32 for the walls' labour organisation.

57 Humm 2005: I68-75.

58 For RRC I3/2, see Burnett 2016.

59 Vagi 20I3: 78-9.

60 Burnett 20I 2; see also Cornell I995: 397; Woytek 20I4: 208 suggests a combination of cultural and economic causes.
} 
provided local elites with a political tool for intra-community competition. ${ }^{61}$ The contested ideological role of Greek culture among the political elite is well known from the culture wars of the second century B.C., but the concept can be extended to the earlier period. ${ }^{62}$ In a classic study of the struggle of the orders, Momigliano drew attention to the contrasting cultural ideologies of patricians and plebeians: 63 while patricians retained cultural links with Etruria and central Italy from the monarchy into the Republic, plebeians looked to Magna Graecia, Sicily and the Greek East. Things were not dissimilar in the period of early coinage, even if the dividing line was no longer strictly between patrician and plebeian. Some prominent families such as the Fabii or Ogulnii maintained connections with Etruria, while others were receptive to Greek practices. ${ }^{64}$ Appius Claudius Caecus, whose contested support of new forms of wealth is considered below, reputedly composed Pythagorean poetry and adopted several features of contemporary Hellenistic culture. ${ }^{65}$

While contested cultural practices are evident in the period of early coinage, it is less clear whether they will have supported monetisation. Mid-republican Roman interactions with Greeks did not always revolve around the use of metal in coined form; on more than one occasion the sources record Greeks gifting Roman magistrates golden crowns of the sort likely common in elite tombs in Magna Graecia. ${ }^{66}$ Unsurprisingly, the Greeks whom Romans encountered used precious metal for elite display and prestige even as they minted coinage. If such complexity makes it less likely that coins arose simply from exposure to Greek culture, it reiterates the need for a more complete analysis of the social roles of metallic wealth including, but not limited to, coinage. This discussion has also emphasised that innovative mid-republican practices were caught up in the competitive struggle for political power, and it is to the potential importance of this background to which I now turn.

When we speak of the Roman 'state' that first produced coins in this period, we use that term to elide a heterogeneous group of elites who not only held different cultural orientations, as noted, but who also espoused different views of metallic wealth and exchange. ${ }^{67}$ It must be acknowledged that Rome's initial production of coinage took place at a time when competition for political power at Rome was increasing. Starting in 367 B.C., a series of laws opened the consulship and other offices to the plebs. Power was no longer restricted to a small hereditary class of patricii; the new nobilitas derived authority from holding high office, military commands and senatorial membership. While the pool of those eligible for high office expanded significantly, the number of offices did not, and the resulting imbalance increased political competitiveness. At the same time, the initial phases of Roman expansion exposed military commanders to unprecedented levels of wealth. It was, as Fabius Pictor claimed, only when they

61 Chrubasik 20I7: I06.

62 Gruen I995.

63 Momigliano I967.

64 Torelli I995: 43-4 on Etruscan connections.

65 Humm 2005: 483-540.

66 Plin., $\mathrm{NH}$ 34.32, 285 B.C., Thurini to C. Aelius; Iustin. I 8.2.8-9, 273 B.C., Ptolemy II to Roman ambassadors; see Masiello I 984 on the material evidence from Italy.

67 Termeer 2016 also disassociates coin production in Samnium and some Latin colonies from abstract notions of a state or uniform political entity; while she leans heavily on a military explanation for coin production, her argument that coinage arises from various sociopolitical configurations is important. 
conquered the Sabines that 'Romans first perceived wealth'. ${ }^{68}$ As Tan shows, ${ }^{69}$ state income from Roman conquest was very much individual wealth, or was acquired largely by individual actors. This will have imbued wealth with strong ideological implications within the competitive political arena.

It is in the context of early Roman conquest in this period that descriptions appear of Roman generals encountering a world of material riches that was wholly foreign to them. Stories about C. Fabricius Luscinus and M.' Curius Dentatus rejecting enemies' offers of gold in deference to their Roman virtues of paupertas and frugalitas quickly became proverbial. Their refusals of wealth are closely related and sometimes confused in the sources. $^{70}$ However, it is worth reading the general thrust of these episodes with the observation of Burnett and Molinari that gold and silver in general, and not merely coins, are comparatively scarce in the record of Rome prior to the Second Punic War. ${ }^{71}$ Their catalogue of literary attestations and archaeological finds is suggestive and may indicate that ideology was having real effects on the circulation of precious metals among Rome's elite.

Of course, metallic wealth was not entirely unknown to the aristocracy of this period, and certain uses of silver and gold featured in the reconfiguration of Roman aristocratic identity. In 304 B.C., when the aedile Cn. Flavius brought forth a series of measures designed to support the political followers of Appius Claudius Caecus, the nobiles resisted him by removing their gold rings and phalerae. The episode is related by Livy in a heavily moralising account that calls the political party of Flavius the factio or turba forensis in opposition to the uiri boni of Fabius Maximus and his conservative peers. Livy's depiction of the Roman elite divided into factions reveals the influence of Gracchan and later republican annalists such as L. Calpurnius Piso. Notably, however, Pliny cites the same detail of the nobiles' removal of their rings from 'antiquissimi annales', while the general Italian practice of wearing gold rings as markers of status in this period may be supported from a variety of evidence including one such ring from Capua inscribed with an Oscan man's name. ${ }^{72}$ If historical, the episode would support the idea that gold functioned in late fourth-century Rome as a medium of aristocratic prestige, rather than as a means of exchange, while we also see an emerging moralising discourse towards those who were apparently outsiders to this social order.

The identity of the political followers of Appius Claudius has prompted significant debate. ${ }^{73}$ Accessing this topic requires engaging closely with the difficult later tradition, but, so far as can be discerned from that material, Appius Claudius' followers do not seem necessarily poorer than those members of the existing nobilitas. All accounts suggest that, when the censor attempted to enroll libertini in the Senate in 3 I 2 B.C., this action was rejected by his aristocratic peers on moral, not technical, grounds. ${ }^{74}$ It would follow therefore that some of the censor's political allies were sufficiently wealthy to qualify for senatorial membership, while the point of contention was rather their

68 Fabius Pictor F24 (FRHist). The fragment gives no historical context other than the conquest of the Sabines but is normally placed in relation to the campaigns of M.' Curius Dentatus.

69 Tan 2017 .

70 For these individuals, see Berrendonner 200I; for sources, consult Torelli I978: 6I-4 (Curius Dentatus), I8990 (Fabricius Luscinus).

71 Burnett and Molinari 201 5 .

72 Imagines Italicae (= Crawford 20 I I) Capua 47, I, 468 (before $c .300$ B.c.), 'Vibius Orfius'. The senators' moral opprobrium expressed by removing their golden paraphernalia is endorsed even by those who view Livy's broader account of Flavius' aedileship as problematic, see Nicolet I96I: 69I-5; more optimistically, Oakley I997-2005: III, 606-I4; Humm 2005: I 24-5.

73 Garzetti I947; Staveley I959; Ferenczy I967; MacBain I980; Loreto I99I; Cornell I995: 373-7; Humm 2005.

74 As noted by Oakley I 997-2005: III, 384 , Livy 30.I-2 offers a particularly morally charged account; however, other sources reveal similar social, rather than purely economic, frictions surrounding Appius' lectio; see e.g. Diod. Sic. 20.36.3, referring to the censor's actions angering senators 'who boasted of their nobility'. 
backgrounds, and the source and form of their wealth. Cn. Flavius himself was supposedly 'born to low fortune' and the son of a freedman, but was curule aedile and thus plausibly a member of the same senatorial class that opposed him. ${ }^{75}$

Livy portrayed Appius' supporters in moral terms: they were humiles not boni. He also described them as an urban group connected with the forum (turba or factio forensis). Again, the language seems reflective of later republican politics, but an urban focus to Appius' political agenda may be detected elsewhere, and not only in the historical tradition. ${ }^{76}$ Appius' aqueduct, for example, terminated in the northern Forum Boarium, where it provided fresh water primarily to Rome's commercial port and to residents in one of the more densely inhabited areas of the mid-republican city. ${ }^{77}$ The idea that Appius' followers were tied in some way to the city and the commercial activity it hosted is also attractive as political innovations of the late fourth century, such as the creation of the urban tribes and the graded census classes, favoured those who possessed moveable and more quantifiable property, and not only landholding. ${ }^{78}$ Even as Appius' actions met resistance, the urban individuals whose political aspirations he sought to support, as well as the forms of wealth upon which they depended, may have started to gain traction within the machinery of Roman politics.

Metallic wealth continues to feature in the record of this ongoing reconfiguration of aristocratic power over the next decades. Metal's role is documented in Livy's meticulous account of the triumphs of L. Papirius Cursor and Spurius Carvilius Maximus in 293 B.C. at I0.46. This passage features in numismatic studies because of the detailed numeration of each triumphator's spoils in silver and bronze for the first time in Livy's narrative, a novelty which has been argued to reflect a new documentary basis if not a real change in economic behaviour. ${ }^{79}$ What also deserves attention is the way in which Livy contrasts the behaviours of each triumphator toward his metallic spoils. The two men came from opposite social backgrounds: Papirius Cursor belonged to an old and prominent gens, and his father was the most distinguished general of the Second Samnite War, while Carvilius was a novus homo and remained an exemplum of social mobility in later Roman history (cf. Vell. Pat. 2.I28.2). Accordingly, each man constructed legitimacy through different systems of value. Papirius Cursor's triumph focused on inherited and symbolic prestige: his spoils were explicitly compared to his father's, and he completed a temple to Quirinus vowed by his father. He hung metal arms and armour captured from the Samnites on Rome's buildings and those of neighbouring communities and deposited most of his wealth in the treasury. His spolia thus had primarily symbolic value, and he refused to use them to pay for ongoing military activity, making it necessary to levy a tax.

By contrast, Carvilius is said to have distributed a portion of his metallic spoils on an individual basis to his cavalry and infantry, giving different amounts according to rank and thus quantifying social distinction. Like Papirius Cursor, he made offerings to the gods, building a temple to Fors Fortuna near an old cult site established by Servius Tullius. ${ }^{80} \mathrm{He}$ also dedicated a statue to Jupiter on the Capitol. But how Carvilius effected these religious acts differentiated him from his consular colleague. Pliny notes that the statue was made from the metal of spoliated arms and armour melted down for the purpose $(H N$ 34.43). Rather than exploit the symbolic value of captured wealth, he

\footnotetext{
75 Livy 9.46.I: 'patre libertino humili fortuna ortus.'

76 For further related passages in the tradition, see, e.g., Livy 9.42.4 on Appius' political influence during his consulship gained through 'urbanis artibus', a difficult phrase on which see Oakley I997-2005: III, 55I.

77 Mignone 20I6: 8I notes that the original specus would not have made water available beyond the terminal distribution point.

78 Humm 2005: 255.

79 Oakley I997-2005: IV, 444-5; see especially Hollstein I998-9.

80 See below, Section V.
} 
transformed it into other forms. Carvilius is said to have made 'from the remaining filings' ('e reliquiis limae') - observe the remarkable specificity over metal - a statue of himself to place at the foot of the god. Clearly, he was not shy about individual ambition.

The account of these triumphs reveals two non-exclusive but opposing systems of value. Points of overlap appear: both consuls' spoils were expressed as money, both made offerings to the gods. However, while Papirius used his spoils to emphasise inherited authority within the aristocratic community, Carvilius, as a nouus homo and without illustrious ancestors, promoted the individual aspects of his accomplishment and did so by transacting or transforming his metallic income. It is less relevant whether either triumphator actually used coins, something we do not know, than that both men held different views of the way in which metal gained in war supported political success. Notably, both ideologies were successful in prolonging political power, since both men were elected to a second consulship in 272 B.C.

The success of these individuals should be seen in a situation of continuing complexity: there remained risks associated with individual wealth, while social capital continued to be found in the rejection of foreign riches, as in those stories of the frugalitas of Curius Dentatus or Fabricius Luscinus. As censor in 275 B.C., the same Fabricius expelled his political rival P. Cornelius Rufinus, 'a greedy man' (Gell., NA 4.8, 'homo auerus'), from the Senate for owning ten pounds of silver plate. This suggests, first of all, that quantified metallic wealth continued to expose individuals to possible moral polemic. The episode is also instructive because Fabricius was in many ways comparable with Carvilius. He was a plebeian nouus homo and reputedly shared generously from his own triumphal spoils with his soldiers. ${ }^{81}$ What is more, Fabricius was remembered to have supported Cornelius' consular candidacy in 277 B.C.; the ambiguity of his actions makes it hard to see his censuring of Cornelius two years later as the product of a simple dichotomy between newcomers and nobiles from older families. ${ }^{82}$ Instead, Fabricius was apparently able to activate different systems of value in particular situations and for particular political aims. All told, this episode forms another in a series of events related by the sources that can be understood to pertain to a coherent shift in the balance of Roman ideologies towards wealth. From the fourth to third century, new forms of wealth, including metallic wealth, gained political standing but also continued to hold potential disadvantage, as several instances of moral opposition would confirm. As a result, the shift in the balance of Roman systems of value was contested and uneven; such characteristics would fit well with the shape of early coinage, which began to be minted in this period, but infrequently and in limited quantity.

Thus far, this reconstruction of Roman coinage's appearance has paid little attention to the best source for the Romans' own view of their monetary history found in the elder Pliny's Naturalis Historia. Pliny's chapters on coinage have prompted near constant debate, with scholarship generally focusing on correlating his claims to the numismatic evidence. ${ }^{83}$ Discrepancies between textual and material records make this task difficult, while recently published material offers no help. The down-dating of ramo secco bars, for

81 Dion. Hal. I9.16.3; Oakley I997-2005: IV, 447.

82 Gell., NA 4.8 provides the fullest extant account and seems to imply that Fabricius' censure was pretext for personal enmity towards Cornelius, something that makes sense considering the suggestion of Burnett and Molinari 20I 5: 78 that the amount of silver was insignificant; Livy, Per. I4; Dion. Hal. 20. I; Val. Max. 4.3.

83 Crawford I974: 35-7; Zehnacker I979; Peruzzi I98 5; Pedroni I993: I9-29; Coarelli 2013: I7-29; differently, Williams 2007. 
example, disputes Pliny's notion that King Servius 'first struck bronze', while the discovery at Poseidonia/Paestum of the first silver didrachm makes it impossible that Rome 'first coined silver' in 269 B.C. Complex arguments around such problems have been advanced but are hard to verify, and I want instead to draw attention to some features of the ideological context of coins' emergence which may be legible in the rhetorical framing of Pliny's monetary history.

The first and most immediate layer of rhetoric detectable in Pliny's account is the schematic of moral decline well known from other parts of his work. In the opening line of Book 33, Pliny established his topic as 'metal, as well as actual wealth and the prices of goods', immediately noting that the substance and symbolic value of metal were separate but overlapping aspects. Early man in his morally pure state had little need for metal in any form and relied instead on barter ('res ipsae permutabantur inter sese'), while the search for metal and its use were morally corrosive. ${ }^{84}$ The impetus to fashion gold into coins was 'proximum scelus', following the 'pessimum uitae scelus' of wearing gold as rings and jewellery (33.8). This general attitude towards metal as a form of luxury picked up on a long tradition in Greco-Roman literature but also can be seen to fit well into the context of Flavian intellectual culture and Pliny's own authorial aims. ${ }^{85}$

A second layer of rhetoric in Pliny's history of coinage may instead shed light on features formed at a particular, earlier moment. Key is the ideological stance implied by Pliny's statement that King Servius first struck bronze coinage at Rome. Some but not all sources conformed to this attribution; Varro credited Servius with silver coinage, while other authors assigned coinage to Numa or to an even earlier period. ${ }^{86}$ Such variance implies a choice behind Pliny's emphasis on the role of Servius. Smith rehabilitates Pliny's awareness of the sources for early Rome and suggests that Pliny knew of various depictions of episodes in early Roman history and selected out of this material on the basis of its appeal to the moralising framework of his work. ${ }^{87}$ In this case, it is worth exploring whether Pliny's choice to follow the Servian attribution was guided by the author's awareness of the populist and anti-aristocratic tradition of the slave-born king who rose to power from obscure origins. In this account, Servius' radical social mobility gave him markedly different prestige than the Tarquins, and a demagogic ideology informed much of his political career. ${ }^{88}$ The king's low social standing was closely and rhetorically linked to coins, money and value. Tarquinius Superbus, for example, could be made to denounce Servius' illegitimate birth in one sentence, and in the following sentence attack the king's reconfiguration of wealth as a threat to the stability of the prevailing social order:

He had instituted the census so that the wealth of the rich would be recognised with envy, and wealth gathered together from whatever source one wished could be distributed to the neediest. ${ }^{89}$

As this passage suggests, the radical step of giving transactional and tangible, and no longer symbolic, form to wealth was most associated with the king's famous census, but similar themes of quantification and commercial exchange emerge across his broader agenda. Servius was held to have invented standardised weights and measures (De vir. ill. 7.8)

84 cf. Nicolet I984.

85 On luxury in Pliny, see Citroni Marchetti I99I; Lao 20 I I.

86 Sources in Thomsen I980: I 8 and I957-6I: I, 25-7.

87 Smith 2007.

88 RE VII.A I s.v. 'Tullius' \$ I 8.I2 coll. 8 I9-20 (W. Hoffmann); for the development of the Servian tradition, see Gabba I969; Ridley I975; Thomsen I980; Vernole 2002.

89 Livy I.47.I 2: 'instituisse census, ut insignis ad inuidiam locupletiorum fortuna esset et parata, unde, ubi uellet, egentissimi largiretur.' 
and to have established the city's nundinae (Macrob., Sat. I.I6.33). Coinage fits well within this context.

However, this Servian ideology of short-order value, so to speak, was not the only way in which Rome's sixth king was remembered. Opposed to the democratic Servius, another version saw the king rule as a tyrant without popular consent. ${ }^{90}$ Then, there is the well-known Etruscan account depicted in the Françoise Tomb frescoes and echoed in Claudius' speech on the Lyon Tablet (Dessau, ILS 212) in which Servius was Mastarna, an Etruscan warlord who accompanied the Vibennae brothers in seizing Rome from the Tarquins. As a 'most faithful comrade' ('sodalis fidelissimus') of the Vibennae, Mastarna's actions were part of the archaic aristocratic world in which social ties, rather than quantifiable wealth, structured society.

We would therefore like to know when prior to Pliny an ideology of quantifiable value and social mobility began to be associated with Servius. At least some of Pliny's information on early Roman money came from Timaeus of Tauromenium (died c. 260 B.C.), who wrote contemporary to the initial development of Roman coinage. However, it is famously difficult to delineate the extent to which Pliny used the Sicilian historian, and attributing Pliny's Servian association with coinage to Timaeus requires us to admit that Timaeus ascribed a contemporary development, the coining of bronze, to a much earlier point in Rome's history. ${ }^{91}$ Of course, Timaeus, as Polybius reminds us, was not infallible; considering the long-standing monetary use of bronze in the Roman economy, it is possible that Timaeus got some details right but incorrectly retrojected others, although it seems incautious to lean too firmly upon the idea.

The existence of a populist Servian ideology can be confirmed by the second century, when political factions of the Gracchan period seized upon it. Accius' depiction of Servius as the king 'who established freedom for the citizens' may already reveal such influence, depending on the date of his Brutus from which the quotation comes. ${ }^{92}$ Gabba suspected that Polybius' archaeology already framed Servius as basileus in contrast to the tyrannos Tarquin. ${ }^{93}$ At least some of Servius' populist reforms, including the census and the tribal system, were described by Fabius Pictor, but the extant fragments make it hard to grasp the ideological register in which he portrayed these actions. $^{94}$ Greek models such as Cleisthenes or Solon, whom ancient sources also associated with monetary innovation, seem relevant, and it was Pais' view that Greek authors of the fourth and third centuries formed the more democratic Servius in connection with plebeian politicians at Rome, but this can only be speculation. ${ }^{95}$

In this attempt to trace the anti-aristocratic Servian tradition backwards into the mid-Republic, some early material evidence other than the Françoise Tomb frescoes has still not been sufficiently considered. ${ }^{96}$ First, a Faliscan red-figure skyphos dated to $c$. 350-3 IO B.C. in the Museum of Fine Arts in Boston bears a scene of a young man killing an older man outside a palace door. Del Chiaro and Massa-Pairault interpret this as the murder of Servius by servants of Tarquinius Superbus on the steps of the curia. This would demonstrate remarkable stability over time in the tradition of Servius as interloper in the Tarquinian line, but it is hard to exclude Beazley's identification of the

\footnotetext{
90 e.g. Cic., Rep. 2.37 .

91 Baron 2013: 49-50, with earlier bibliography. The first half of the statement, 'Servius rex primus signauit aes. antea rudi usos Romae Timaeus tradit', may, but does not necessarily, rest on the same source as the second.

92 'Tullius, qui libertatem ciuibus stabiliuerat' (Brutus F4 (Dangel) = Cic., Sest. 58.I23); Dangel I995: ad loc. points out that Accius was aligned with the optimates, complicating matters.

93 Gabba I969.

94 cf. Fabius Pictor F9-Io (FRHist).

95 Pais I905: I4I-2.

96 See Vernole 2002: 2I-2 on Thomsen I980.
} 
scene as the murder of Aegisthus by Orestes. ${ }^{97} \mathrm{~A}$ second, potentially firmer witness to the early Servian tradition is the so-called Fiesole sors, an archaic Latin inscription carved in relief on a round cobble, perhaps an oracular lot. ${ }^{98}$ Current consensus dates the object, largely on linguistic grounds, to c. 300 B.c. ${ }^{99}$ The text reads, 'se ceduas perdere nolo ni ceduas fortuna Servios perit'. While the overall meaning remains debated, for present purposes the reference to both Servius and fortune or, more probably, Fortuna, is clear and attests to an 'almost proverbial' relationship between king and deity by that date. ${ }^{100}$

Servius' connection to Fortuna is of great importance in the later popular tradition as the king lavished religious attention on the goddess of individual fate. Fortuna was held to have cultivated both Servius' ascent to power from humble origins and to have contributed to the king's downfall and murder. ${ }^{101}$ It bears stressing that the Fiesole inscription would affirm the existence of a connection of some sort between Servius and the deity by around the start of the third century. In turn, the mention of Fortuna at that time raises another potential parallel in the figure of Appius Claudius, whose actions have often been recognised as reflecting themes and aspects of the popular Servian tradition. ${ }^{102}$ In particular, the famous sententia attributed to Appius Claudius also contained reference to fortuna: 'Every man is master of his own fortune' ('fabrum esse suae quemque fortunae'). ${ }^{103}$ Considering Appius' attempt to integrate Romans with few social ties into the political community, it is telling to find the censor championing the supremacy of the individual, a political ideology that seems consonant with Servius' rise to power from humble origins. The censor's sentiment may have drawn upon broader intellectual currents in circulation at that time: Dupraz notes some version of 'faber fortunae' in Plautus and several other authors, as well as in an Oscan epitaph from Corfinium where the phrase follows immediately on a claim to have achieved great personal wealth; ${ }^{104}$ he argues that Appius co-opted a widely known Sabellic proverb, although the Corfinium epitaph is late, and the degree to which it has been influenced by Latin idiom, not vice versa, is controversial. ${ }^{105}$ Still, Appius' sententia itself, when read alongside the Fiesole inscription, supports the idea of some role played by fortuna both in the political ideology espoused by the censor and applied to the career of Servius, at roughly the same date in the mid-Republic.

It is thus not only possible that Pliny's attribution of coinage's invention to Servius was guided by the king's association with an ideology of wealth, value and social mobility, but this ideology may be seen to gain prominence around the time of Rome's first coinage. Further support for an early third-century connection between fortuna, Servius and a certain system of value might be found in the appearance of these elements together again in Livy's account of the triumph of Spurius Carvilius in 293 B.C., discussed above. Carvilius' transactional approach to his metallic spoils may be seen as ideologically linked to his dedication of a temple to Fors Fortuna beside a sanctuary attributed to

\footnotetext{
97 Del Chiaro I974: 23-4; Massa-Pairault 2014; contra Beazley I947: I66-7, 303; problematically, the tragedies of the house of Atreus exerted an early influence on the Servian legend, see Ogilvie I965: I86, and this makes distinguishing the iconography difficult.

98 For the object's function, see Klingshirn 2006: I4 I-2.

99 Extensive treatment in Del Tutto et al. 2002; see also Coarelli I988: 302; 2000; Smith 20 I I: 40; Humm 2005: 363 .

100 Smith 20II: 40; see Del Tutto et al. 2002 for the semantic overlap between Fortuna and fortuna.

101 Champeaux I982: I95-8; Coarelli I988: 253-77.

102 For multiple parallels between Appius and Servius, see Humm 2005: 360-2, with previous bibliography.

103 Appius Claudius, Carmina fr. 3 (Blänsdorf), cited obliquely at [Sall.] Epist. I.I.2: 'fabrum esse suae quemque fortunae'. Restoring the original text remains difficult, as cf. Mercado 20 I 2: 3 I 7 n. I77 on 'ill-advised' attempts to make this a Saturnian line. However, as Cornell I989: 399 notes, there are no good grounds for dismissing the fragment's authenticity.

104 Dupraz 2005.

105 Imagines Italicae (= Crawford 20 I I) Paeligni/Corfinium I I, I.273 (first century B.C.): 'solois des / forte faber', equating in Latin to 'omnibus dives / fortunae faber'. Cf. Adams 2003: I4 I-2.
} 
Servius. King and deity would have provided affirmation for the nouus bomo consul's acquisition of political power from sources of value other than the inherited and symbolic prestige upon which his colleague Papirius Cursor relied. ${ }^{106}$ In a sense, Carvilius was master of his own fortune, and it is in the context of the increasing socio-political standing of figures like him that Rome's initial production of coins can be understood.

The argument thus far is for a model in which the dramatic increase of wealth from conquest starting around 300 B.C. disrupted the stability of the ruling order; as wealth and political power were reconfigured, Romans started to produce coinage, but tentatively, as some but not all members of the nobilitas embraced the system of value to which coins pertained. What changed by the later third century when the Roman monetary economy expanded with the quadrigatus and, ultimately, the denarius? Answering this question on purely numismatic grounds proves difficult. The central decades of that century are comparatively poorly documented by hoards. Even as recently discovered deposits from San Martino in Pensilis or Nora shed new light on circulation, the issue may be more fundamental, as precious metal coinage virtually ceases in South Italy by c. 250 B.C. ${ }^{107}$

Rather than pursue numismatic developments strictly defined, I want to emphasise the continuing dynamics of Roman systems of value by looking at broader patterns of production and the exchange of impersonal wealth. Several indications primarily derived from recent archaeological work suggest transformations in the intensity of Roman agriculture and the extent of commercial activity in the wake of the First Punic War. ${ }^{108}$ The last few decades of excavation in Rome's suburbium have identified several dozen medium-to-large farmsteads in the city's immediate hinterland with initial construction phases in the third century. In the same moment, a handful of earlier sites were reconfigured with architectural features recognisable from slave-staffed villas of the later Republic and Empire. ${ }^{109}$ The scale of this new pattern of land tenure would increase in later periods, but the villa system's roots were nonetheless established prior to the Second Punic War. Many of these mid-republican farms exhibit unprecedented signs of intensive production including wool-working and especially viticulture, archaeologically detectable in the form of furrows dug for the irrigation of vines. ${ }^{110}$

Much of the wine and other commodities grown in the suburbium were aimed at markets in the capital, where attention was increasingly devoted to urban market-places. Sources present the development of market-places in third-century Rome within an ideologically contested arena. The Lex Hortensia de nundinis of 287 в.C., for example, specifically forbade the holding of comitia at Rome on the same days as nundinae, and may have been prompted by the desire to exclude those who sold or bought goods at periodic markets from participating in political assemblies. ${ }^{111}$ Meanwhile, Rome's first permanent market hall was constructed beside the forum sometime before the Second Punic War. Valerius Maximus' exempla of men 'born in low station who became illustrious' included M. Terentius Varro (cos. 216) whose father operated a shop in the

\footnotetext{
106 Fors Fortuna was particularly associated with craftsmen, traders and freed slaves, that is, Romans without social standing; Champeaux I982: 234-6; Humm 2005: 363 .

107 Rutter 200I: 8.

108 Gabba I98I; Cibecchini and Principal 2002; Morel 2007; Volpe 2009; Panella 2010.

109 Volpe 2012.

110 For wool-working, see Piranomonte and Ricci 2009 on the Viale Tiziano site. For viticulture, see Volpe 2009.

111 Michels I967: 103-6.
} 
macellum (3.4.4). According to Valerius, Fortuna - appearing in the context of wealth and social mobility once again - guided Varro's career from this 'most vulgar' (sordidissimae) form of profit-making.

Beyond the urbs, signs appear at this time of Roman involvement in intensive agriculture and maritime commerce across an expanding territory. It is possible that members of the senatorial class owned vineyards in Sicily by the time of Hiero II. ${ }^{112}$ Campania and the Bay of Naples drew the attention of Roman producers, as is confirmed by Roman names found in stamps or dipinti on third-century Greco-Italic amphorae produced in that region. ${ }^{113}$ Starting c. 250 B.C., shipwrecks laden with these transport containers attest to the first significant cargoes of Italian wine exported into the western Mediterranean. ${ }^{114}$ The shape of these amphorae changed over the third century, with the originally top-like profile and flaring lip progressively replaced by a more streamlined body and downward-turned lip. This down-turned lip seems to have been made to fit against the body profile of another amphora when loaded in two layers in a ship's hull. ${ }^{115}$ In this way, the shape of these amphorae increasingly accommodated bulk transport and more efficient cargoes. The pots thus anticipate the stackable Dressel I amphorae, which served for the large-scale export of Italian wine over the last two centuries of the Republic, just as larger estates in the third-century suburbium can be seen to anticipate the great late republican wine-growing villas at Settefinestre and elsewhere.

While several Roman names on Greco-Italic amphorae are obscure, others belong to old patrician gentes including the Aemilii and Valerii. ${ }^{116}$ This material speaks to the involvement of members of noble families in some aspect of the marketing of wine. Most inscriptions give no information about personal status, making it impossible to know whether named individuals were free or slave, or whether they were traders, shipowners or even proprietors of land on which wine carried in these vessels was cultivated. But the participation of at least one consul in this wine trade is confirmed by the recent discovery of a Greco-Italic amphora from a site near Ostia with an inscription on its neck reading in part ' $\mathrm{M}$. Val(erius) $\operatorname{co}(\mathrm{n}) \mathrm{s}(\mathrm{ul})$ '. ${ }^{117}$ Meanwhile, Olcese draws attention to the fact that many abbreviated Greek names on Greco-Italic amphorae produced around the Bay of Naples also appear as sigla on Neapolitan didrachms minted around the same time. ${ }^{118}$ The question of whether such sigla belong to coin engravers or moneyers remains unsettled, but this would not be the only place in the Hellenistic world where marks on coins and amphorae related to similar individuals. ${ }^{119}$ It is not difficult to imagine that part of the Neapolitan aristocracy dependent on the commercialisation of wine overlapped with the political elite who controlled the city's coin production.

The idea that the third-century Roman state increasingly comprised noble families involved in marketing wine may also be reflected in several legal measures seemingly intended to give such activity institutional support. Festus $(288 \mathrm{~L})$ records an otherwise undated Plebiscitum de ponderibus publicis passed by the tribunes P. and M. Silius which fixed official metrological standards for measures of vinus, although wine here probably stood in for a broader guideline for liquid and dry goods of various sorts. ${ }^{120}$

\footnotetext{
112 Zevi 2002: 46-7.

113 Van der Mersch 200I; Panella 2010.

114 Cibecchini and Principal 2002.

115 Wallinga I 964: $33-4$

116 Van der Mersch 200I.

117 Olcese and Coletti 20I6: I25. Four Marci Valerii held the consulship between 226 and I6I B.C.

118 Olcese 2010: 77-8.

119 For debate over the Neapolitan sigla, see Marchetti I986; for connections between stamps on coins and amphorae, see Finkielsztejn 2006.

120 Cloud I985; Crawford I996: II, 737-9.
} 
One can only speculate whether the passage of this legislation was linked to the evolving ideology of Servius, who was associated at some point with similar measures. The law presumably came after the Lex Hortensia of 287 B.C. made plebiscites binding on the Roman community, and before the Lex Claudia of 2 I9 B.C., which employed amphorae as a unit of measurement. This timeframe presents a potential relationship with the Greco-Italic amphorae, which not only became more streamlined in shape but also exhibited progressively stricter standard volumes through the later third century. ${ }^{121}$ Whether or not the law was directly responsible for this development, parallel trends are observable in metrological standardisation in both the institutional and archaeological record.

The Claudian law restricting senators and their families from owning sea-going vessels of larger capacity than 300 amphorae is of the utmost importance to this discussion. Livy, who provides the only extant account of the law's context, reports that the law was intended to limit the transport of large cargoes laden in hopes of profit, because 'all profit from trade was deemed inappropriate for senators' ('quaestus omnis patribus indecorus uisus'). This moralising pretext has been attacked as mere Livian rhetoric, but the archaeology of third-century Roman trade makes such scepticism unwarranted: as noted, the cargoes in question will have comprised Greco-Italic amphorae. ${ }^{122}$ Tchernia defends the measure as a sort of Lex de modo agrorum, since permissible tonnages would have served for the conveyance of wine from estates of no more than $c$. IO-20 iugera. ${ }^{123}$ Larger estates, including some of those discovered in Rome's suburbium, must have been targeted by the measure, which in his view was reactive as much as proscriptive. I leave aside the difficult question of the law's real effects on senatorial behaviour and stress instead the implication that by 2 I9 B.C. a sizeable proportion of the political elite practised commercial viticulture. The Claudian law provoked an almost universally negative response (so Livy claims) from the nobilitas, a reaction that can be read as a contested attempt to reassert the dominance of symbolic value in the face of rising participation in impersonal wealth-production and exchange.

All told, more Roman senators seem to have been favourable to commercial activity on the eve of the Second Punic War than a century prior, when Appius Claudius Caecus struggled to incorporate his forensis factio into the structures of political power. The shape of this development resembles that of Roman coin production from its small-scale beginnings to the much larger coinage starting sometime in the decades after the First Punic War. The parallel is unsurprising considering the changing complexion of the political class in charge of coin production. By emphasising the level of elite participation in Roman trade as it compares to the rapid escalation of coin production, I do not mean to equate senatorial trade with coinage in a direct manner. ${ }^{124}$ The point is rather that trade and coins pertain to a similar system of value. As external or less traditional wealth gained political traction, Roman elites were more likely to apply coins to a wider range of transactional needs.

By no means did the creation of the denarius system in the late third century and the progressively deeper monetisation of the Roman economy signal an end to the contestation of value and political authority. Wealth along with a discourse over its

\footnotetext{
121 Panella 20IO: I4-I 5 .

122 Morel 2007: 500-I.

123 Tchernia 2016.

124 cf. Burnett I989: 5I-3.
} 
appropriate means were by that point integral parts of senatorial identity. ${ }^{125}$ In the eulogy for Q. Caecilius Metellus (cos. 25 I and 247) delivered in 22 I B.C., his son would boast that his father gained 'great wealth in an appropriate way'. ${ }^{126}$ Such qualification of the way in which an aristocrat was supposed to make his fortune anticipated Cato's famous advice that uiri boni restrict themselves to agriculture and stock-ranching. ${ }^{127}$ Of course, Cato himself also reputedly engaged in the 'most disreputable' activity of making maritime loans, ${ }^{128}$ but this should not surprise us: participation in one or the other transactional order was rarely if ever exclusive. This discussion of different paths to wealth in Roman society and their moral contestation could be extended almost infinitely; we have seen its continuation in the writings of Pliny. Rather than pursue the theme further, I want to recapitulate my argument for understanding early Roman coinage within the evolving dynamics of mid-republican society as it understood wealth's relationship to political power. Those who found it acceptable to make money in certain ways will have found it acceptable to produce and use coins, and Roman coinage depended upon the proportion of such individuals in the senatorial nobilitas. It may be objected that no source explicitly reveals what coins meant to the mid-republican aristocracy, but this problem is neither unique to the period nor much of an obstacle once we account for the broader socially-constructed system of value to which coins pertained. ${ }^{129}$ This study has traced the contours of a significant shift in the mid-republican political elite's accommodation to impersonal and less symbolic wealth gained through conquest and commercial opportunities in its wake. Rome's society and its political economy transformed radically, and the appearance of coins related to this transformation.

This contextualised perspective seems to me the best way to explain the particularities of early Roman coinage from its small-scale production around 300 B.C. to its rapid expansion leading up to the Second Punic War. The model put forward has the benefit of finding convergence between Roman attitudes towards wealth as gleaned from the historical sources and the independent records of archaeology, epigraphy and numismatics. Perhaps the shape of Rome's initial coinage as elaborated here defies expectations for a major state in the century after the death of Alexander the Great. By one calculation, Rome fought and won the First Punic War with a seventieth of the volume of coinage produced by its opponent. ${ }^{130}$ Noting this, Coarelli recently argued that the slow and late adoption of silver coinage implies a pessimistic and impossibly 'primitivist' view of mid-republican Rome during a period of rapid imperial expansion. ${ }^{131}$ However, by now it should be abundantly clear that powerful states did not require coinage, nor can coins serve as a facile index of complexity. It seems banal to insist that different states had different structures. In the Politics, Aristotle noted that Carthage, as opposed to Greek oligarchies, was unusually open to personal wealth and encouraged its magistrates to earn money from trade (1273a, I3I6b). Polybius, fully aware of Aristotle's views, contrasted the institutional structures of Rome and Carthage, a distinction which encompassed the discrepant roles of money in politics $(6.56 . \mathrm{I}-5)$. It is not hard to extend such differences to each state's production of coinage.

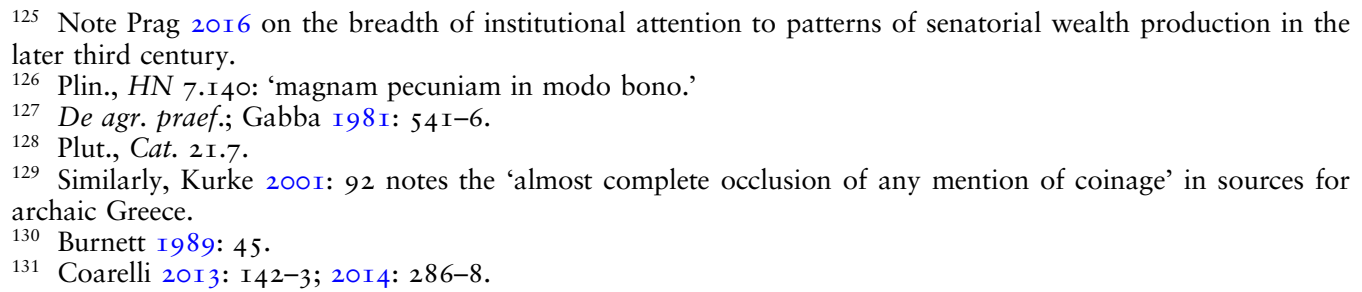


In more general terms, this primitivist critique strikes me as unhelpful for the entire economic study of mid-republican Rome. ${ }^{132}$ This article has sought to explain coinage's appearance in a world in which economic behaviour was unable to be disentangled from social structures. The resulting picture is of an embedded economy that was neither primitive nor static as a result. One thing need not imply the other, and economists have devoted considerable recent attention to social structures, emphasising the role of social relationships and beliefs in economies both historical and modern. ${ }^{133}$ Not only this theoretical discussion, however, but even a more empirical approach militates against any purely fiscal explanation for early Roman coinage. The numismatic evidence simply does not support the idea that Rome's first coin production, small in scale and uneven in character, was conceived of solely to meet items in the state budget. That is, while Romans no doubt paid for public costs increasingly in coin, this does not explain why they minted coins in the first place. Instead, I have focused on coinage's implication in broader change. The expansion of Roman market-oriented production and maritime commerce in the late third century came about as elites sought through impersonal forms of wealth to access a political system formerly monopolised by symbolic wealth and strong social ties. This development and the monetisation it supported were not the inevitable results of modernisation in a capitalistic sense, but the guiding principle of change was the evolving character of Rome's socio-political order. In this context, it is noteworthy that conquest itself became comprehensible in terms of individual wealth. Thus, Polybius' claim that Rome's fateful decision to go to war in Sicily resulted from the desire of the populus for personal ( $\alpha \alpha \tau^{\prime}$ isi $\left.\alpha v\right)$ gain (I.I I.2). ${ }^{134}$ What does all of this entail for Rome's first turn to coinage? Rather than being devoid of economic meaning, coinage's appearance reveals the deep interrelationship of social, political and economic factors at a formative moment when imperial power first began to restructure mid-republican society.

University of Toronto

seth.bernard@utoronto.ca

\section{BIBLIOGRAPHY}

FRHist $=$ T. Cornell (ed.), The Fragments of the Roman Historians (3 vols), Oxford, 2013. $R R C=$ Crawford 1974 .

Aarts, J. 2005: 'Coins, money, and exchange in the Roman world: A cultural-economic perspective', Archaeological Dialogues I2.I, I-28.

Adams, J. N. 2003: Bilingualism and the Latin Language, Cambridge.

Andreau, J. 1987: La Vie financière dans le monde romaine. Les métiers de manieurs d'argent (IV siècle av. J.-C.-III eiècle ap. J.-C.), Rome.

Ashton, R., and Hurter, S. (eds) I 998: Studies in Greek Numismatics in Memory of Martin Jessop Price, London.

Baron, C. 2013: Timaeus of Tauromenium and Hellenistic Historiography, Cambridge.

Beazley, J. D. 1947: Etruscan Vase Painting, Oxford.

Bernard, S. 2016: 'Debt, land, and labor in the early republican economy', Phoenix 70, 317-38.

Bernard, S. 20I7: 'The quadrigatus and Rome's monetary economy in the third century', Numismatic Chronicle $\mathrm{I} 77,50 \mathrm{I}-\mathrm{I} 3$.

132 It is also worth noting that several decades of scholarship have largely swept away this sort of debate; for a critique of primitivism and modernism, see Saller 2005.

133 Granovetter 2005; North 2005: 48-50 on 'the intimate interrelationship of beliefs and institutions'.

134 On this passage, see Tan 20I3; similar tendencies might be read in Rome's decision to expand the war following the sack of Acragas, Polyb. I.I9.I 5-20.I. 
Berrendonner, C. 200I: 'La construction de la tradition sur C. Fabricius Luscinus et M. Curius Dentatus. Un homme nouveau peut-il être un grand homme?', in M. Coudry and T. Spaeth (eds), L'Invention des grands hommes de la Rome antique, Paris, 97-II 6.

Bispham, E., and Rowe, G. (eds) 2007: Vita vigilia est: Essays in Honour of Barbara Levick, London.

Böckh, A. I 834: Metrologische Untersuchungen über Gewichte, Münzfüsse und Masse des Alterthums in ibrem Zussamenhange, Berlin.

Bourdin, S. 201 2: Les Peuples de l'Italie préromaine, Rome.

Bresson, A. I987: 'Aristote et le commerce extérieur', Revue des Études Anciennes 89, 217-38.

Burnett, A. M. I977: 'The coinages of Rome and Magna Graecia in the late fourth and third centuries B.C.', Revue Suisse de Numismatique 56, 92-121.

Burnett, A. M. I986: 'The iconography of Roman coin types in the third century BC', Numismatic Chronicle I46, 67-75.

Burnett, A. M. 1989: 'The beginnings of Roman coinage', Annali dell'Istituto Italiano di Numismatica 36, 33-64.

Burnett, A. M. I998: 'The Romano-Campanian silver', in La Monetazione romano-campana. Atti del X Convegno del Centro Internazionale di Studi Numismatici, Napoli I8-19 giugno I993, Rome, I9-48.

Burnett, A. M. 2006: 'Reflections on the San Martino in Pensilis hoard', Revue Numismatique I62, 37-50.

Burnett, A. M. 20I 2: 'Early Roman coinage and its Italian context', in W. E. Metcalf (ed.), The Oxford Handbook of Greek and Roman Coinage, Oxford, 297-3 I 5.

Burnett, A. M. 20I6: 'Rome's first silver fraction', in M. Asolati, B. Callegher and A. Saccocci (eds), Suadente nummo vetere. Studi in onore di Giovanni Gorini, Padua, I43-8.

Burnett, A. M., and Crawford, M. H. I998: 'Overstrikes at Neapolis and coinage at Poseidonia-Paestum', in Ashton and Hurter I998, 5 5-7.

Burnett, A. M., and Crawford, M. H. 20I4: 'Coinage, money, and mid-Republican Rome: reflections on a recent book by Filippo Coarelli', Annali dell'Istituto Italiano di Numismatica 60, 23 I-65.

Burnett, A. M., and McCabe, A. 2016: 'An early Roman struck bronze with a helmeted goddess and an eagle', in L. Sole and S. Tusa (eds), Nomismata. Studi di numismatica antica offerti ad Aldina Cutroni Tusa per il suo novantatresimo compleanno, Ragusa, 238-74.

Burnett, A. M., and Molinari, M. C. 20I 5: 'The Capitoline hoard and the circulation of silver coins in Central and Northern Italy in the third century BC', in P. G. van Alfen, G. Bransbourg and M. Amandry (eds), FIDES. Contributions to Numismatics in Honor of Rick Witschonke, New York, 2 I-I 26.

Carruthers, B. G. 2005: 'The sociology of money and credit', in N. J. Smelser and R. Swedberg (eds), The Handbook of Economic Sociology (2nd edn), Princeton, 355-78.

Catalli, F. 200I: La monetazione romana repubblicana, Rome.

Champeaux, J. I982: Fortuna. Le culte de la fortune à Rome et dans le monde romain. I: Fortuna dans la religion archaïque, Rome.

Chrubasik, B. 20I7: 'From pre-Makkabaean Judaea to Hekatomnid Karia and back again', in B. Chrubasik and D. King (eds), Hellenism and the Local Communities of the Eastern Mediterranean, 400 BCE-250 CE, Oxford, 83-I09.

Cibecchini, F., and Principal, J. 2002: 'Alcune considerazioni sulla presenza commercial romano-italica nella penisola iberica prima della seconda guerra punica', L'Africa Romana I4, 653-64.

Citroni Marchetti, S. I991: Plinio il Vecchio e la tradizione del moralismo romano, Pisa.

Cloud, J. D. I985: 'A lex de ponderibus (Festus, p. 288 L)', Athenaeum 63, 405-18.

Coarelli, F. I985: Il Foro Romano, 2. Periodo repubblicano e augusteo, Rome.

Coarelli, F. I988: Il Foro Boario, Rome.

Coarelli, F. 2000: 'Il Lucus Pisaurensis e la romanizzazione dell'Ager Gallicus', in C. Bruun (ed.), The Roman Middle Republic: Politics, Religion, and Historiography c. 400-I33 B.C., Rome, I95-206.

Coarelli, F. 20I3: Argentum signatum. L'origini della moneta d'argento a Roma, Rome.

Coarelli, F. 20I4: 'Risposta a A. M. Burnett and M. H. Crawford', Annali dell'Istituto Italiano di Numismatica 60, 267-89.

Colonna, G. I988: 'I Latini e gli altri popoli del Lazio', in G. Pugliese Carratelli (ed.), Italia omnium terrarum alumna, Milan, 4I I-528. 
Cornell, T. J. I989: 'The conquest of Italy', in F. W. Walbank, A. E. Astin, M. W. Frederiksen and R. M. Ogilvie (eds), Cambridge Ancient History vol. 7.2: The Rise of Rome to 220 B.C., Cambridge, 35I-4I9.

Cornell, T. J. I 995: The Beginnings of Rome, London.

Crawford, M. H. I974: Roman Republican Coinage (2 vols), Cambridge.

Crawford, M. H. I976: 'The early Roman economy, 753-280 B.C.', Mélanges Huergon I, Rome, I97-207.

Crawford, M. H. 1985: Coinage and Money under the Roman Republic, Berkeley.

Crawford, M. H. 2003: 'Thesauri, hoards, and votive deposits', in O. de Cazanove and J. Scheid (eds), Sanctuaires et sources. Les sources documentaires et leurs limites dans la description des lieux de culte, Naples, 69-84.

Crawford, M. H. (ed.) I996: Roman Statutes (2 vols), London.

Crawford, M. H. 20I I: Imagines Italicae: A Corpus of Italic Inscriptions (3 vols), London.

Dangel, J. 1995: Accius. Oeuvres (Fragments), Paris.

Debaes, P. 2007: 'Quand Ogulnius frappe le quadrigat ...', in G. Moucharte et al. (eds), Liber amicorum Tony Hackens, Louvain-la-Neuve, I79-9I.

Debernardi, P., and Legrand, O. 20I4: 'The dates of the quadrigati', Annali dell'Istituto Italiano di Numismatica 60, 209-30.

Debernardi, P., and Legrand, O. 2015: 'Roman Republican silver coins of the quadrigatus period struck in Spain', Revue Belge du Numismatique I6I, 273-92.

Del Chiaro, M. I974: The Etruscan Funnel Group: A Tarquinian Red-figured Fabric, Florence.

Del Tutto, L., Prosdocimi, A. L., and Rocca, G. 2002 : 'Lingua e cultura intorno al 295 a.C.: tra Roma e gli Italici al nord', in D. Poli (ed.), La Battaglia del Sentino. Scontro fra nazioni e incontro in una nazione, Rome, 407-664.

Dupraz, E. 2005: 'Un fragment d'Appius Claudius Caecus (Blänsdorf 3) et la tradition poétique sud-picenienne', Lalies 25, 245-68.

Ferenczy, E. 1967: 'The censorship of Appius Claudius Caecus', Acta Antiqua I 5, 27-6I.

Finkielsztejn, G. 2006: 'Production et commerce des amphores hellénistiques: récipients, timbrage et métrologie', in R. Descat (ed.), Approches de l'économie hellénistique, Saint-Bertrand-de-Comminges, I7-34.

Fischer-Bossert, W. I999: Chronologie der Didrachmprägung von Tarent, 510-280 v.Chr., Berlin.

Gabba, E. I969: 'Studi su Dionigi da Alicarnasso', Athenaeum 39, 98-I 21.

Gabba, E. I98I: 'Ricchezza e classe dirigente romana fra III e I sec. a.C.', Rivista storica italiana 9, $34 \mathrm{I}-58$.

Gabrielli, C. 2003: Contributi alla storia economica di Roma repubblicana. Difficoltà politico-sociali, crisi finanziaria e debiti fra 5. e 3. sec. a.C., Como.

Garzetti, A. I947: 'Appio Claudio Cieco nella storia politica del suo tempo', Athenaeum 25, I75224.

Giardino, C., and Lugli, F. 200I: 'L'attività siderurgica nel giardino romano', Bullettino della Commissione Archeologica Comunale di Roma I02, 327-8.

Gorini, G. 20Ir: 'L'offerta della moneta agli dei. Forma di riligiosità privata nel mondo antico', Antenor I9, 245-56.

Gorini, G. 2016: 'A new hoard of Romano-Campanian coins from Nora (Sardinia)', in R. Bland and D. Calomino (eds), Studies in Ancient Coinage in Honour of Andrew Burnett, New York, 3 I-40.

Graeber, D. 201 I: Debt: The First 5,000 Years, London.

Granovetter, M. 2005: 'The impact of social structure on economic outcomes', Journal of Economic Perspectives I9.1, 33-50.

Granovetter, M. 2017: Society and Economy: Framework and Principles, Cambridge, MA.

Grierson, P. 1977: The Origins of Money, London.

Gruen, E. I995: Culture and National Identity in Republican Rome, Cornell.

Hollstein, W. I998-9: 'Uberlegungen zu Datierung und Münzbildern der romischen Didrachmenpragung', Jabrbuch für Numismatik und Geldgeschichte 48/9, I33-64.

Hopkins, J. 20I 6: The Genesis of Roman Architecture, New Haven.

Horden, P., and Purcell, N. 2000: The Corrupting Sea, London.

Howgego, C. I990: 'Why did ancient states strike coins?', Numismatic Chronicle I 50, I-25.

Howgego, C. 2013: 'The monetization of temperate Europe', Journal of Roman Studies I03, I6-45.

Humm, M. 2005: Appius Claudius Caecus. La république accomplie, Rome.

Humphrey, C. I985: 'Barter and economic disintegration', Man 20.I, 48-72. 
Ingham, G. I996: 'Money is a social relation', Review of Social Economy 54.4, 507-29.

Jaia, A. M., and Molinari, M. C. 20 I I: 'Two deposits of aes grave from the sanctuary of Sol Indiges', Numismatic Chronicle I 7 I, 87-97.

Jolivet, V., Pavolini, C., Tomei, M. A., and Volpe, R. (eds) 2009: Suburbium II. Il suburbio di Roma dalla fine dell'età monarchia all nascità del sistema delle ville (V-II secolo a.C.), Rome.

Kim, H. 200I: 'Small change and the moneyed economy', in P. Cartledge, E. Cohen and L. Foxhall (eds), Money, Labour, and Land: Approaches to the Economies of Ancient Greece, London, 44$5 \mathrm{I}$.

Klingshirn, W. E. 2006: 'Inventing the sortilegus: lot divination and cultural identity in Italy, Rome, and the provinces', in C. E. Schultz and P. B. Harvey, Jr. (eds), Religion in Republican Italy, Cambridge, I37-6r.

Kroll, J. 2008: 'The monetary use of weighed bullion in Archaic Greece', in W. V. Harris (ed.), The Monetary Systems of the Greeks and Romans, Oxford, I 2-72.

Kurke, L. I999: Coins, Bodies, Games, and Gold: The Politics of Meaning in Archaic Greece, Princeton.

Kurke, L. 200I: 'Money and mythic history: the contestation of the transactional orders in the fifth century BC', in W. Scheidel and S. von Reden (eds), The Ancient Economy, Edinburgh, 87-I I3.

Lao, E. 20II: 'Luxury and the creation of a good consumer', in R. Gibson and R. Morello (eds), Pliny the Elder: Themes and Contexts, Leiden, 35-56.

Laurence, R. I999: The Roads of Roman Italy: Mobility and Cultural Change, London.

LeRouxel, F. 20I 5: 'Bronze pesé, dette et travail contraint (nexum) dans la Rome archaïque (vi ${ }^{\mathrm{e}}$ s.-iv ${ }^{\mathrm{e}}$ s. a. C.)', in J. Zurbach (ed.), La Main-d'oeuvre agricole en Méditerranée archaïque, Bordeaux, I09-52.

Lo Cascio, E. I980-I: 'Il primo denarius', Annali dell'Istituto Italiano di Numismatica 27/8, 335-8.

Lo Cascio, E. I98I: 'State and coinage in the late Republic and early Empire', Journal of Roman Studies 7I, 76-86.

Loreto, L. I99I: 'La censura di Appio Claudio, l'edilità di Cn. Flavio e la razionalizzazione delle strutture interne dello stato romano', Atene e Roma 36, I8 I-203.

MacBain, B. I980: 'Appius Claudius Caecus and the Via Appia', Classical Quarterly 30.2, 356-72.

Marchetti, P. 1986: 'En guise d'épigraphie monétaire', in La monetazaione di Neapolis nella Campania antica. Atti del VII Convegno del Centro Internazionale di Studi Numismatici, Napoli 20-24 aprile 1980, Naples, 443-68.

Marchetti, P. I993: 'Numismatique romaine et histoire', Cahiers du Centre Gustav Glotz 4, 25-65.

Masiello, L. I984: 'Corone', in E. M. De Juliis (ed.), Gli ori di Taranto in età ellenistica, Milan, 69I08.

Massa-Pairault, F. H. 20I4: 'Le skyphos 97.372 de Boston: scènes "historiques" et histoire du iv ${ }^{e}$ siècle av. J.-C.', in L. Ambrosini and V. Jolivet (eds), Les Potiers d'Etrurie et leur monde: Contacts, échanges, transferts. Hommage à Mario del Chiaro, Paris, 38 I-96.

Mattingly, H., and Robinson, E. S. G. I938: 'The earliest coinage of Rome in modern studies', Numismatic Chronicle and Journal of the Royal Numismatic Society I8, I-35.

Mattingly, H. B. I99I: 'The Roma/Victory Romano didrachms and the start of Roman coinage', in R. Martini and N. Vismara (eds), Ermanno A. Arslan Studia Dicata, 26I-90.

Maurer, B. 2006: 'The anthropology of money', Annual Review of Anthropology 35, I 5-36.

Mercado, A. 20I 2: Italic Verse. A Study of Poetic Remains of Old Latin, Faliscan, and Sabellic, Innsbruck.

Michels, A. I967: The Calendar of the Roman Republic, Princeton.

Mignone, L. 2016: The Republican Aventine and Rome's Social Order, Ann Arbor.

Milazzo, F. I993: La realizzazione delle opere publiche in Roma arcaica e repubblicana: munera e ultro tribute, Naples.

Mitchell, R. E. I966: 'A new chronology for the Romano-Campanian coins', Numismatic Chronicle 6, 65-70.

Molinari, M. C. 2004: 'Un ripostiglio di aes grave proveniente dai Colli Vaiticani (Roma)', Bullettino della Commissione Archeologica Comunale di Roma I05, I I 5-22.

Momigliano, A. 1967: 'Osservazioni sulla distinzione fra patrizi e plebei', in Les origins de la République romaine, Fondation Hardt, Entretiens I3, Vandoeuvres-Genève, I99-22I.

Morel, J.-P. 2007: 'Early Rome and Italy', in W. Scheidel, I. Morris and R. Saller (eds), The Cambridge Economic History of the Greco-Roman World, Cambridge, 487-5 I0.

Nicolet, C. I96I: 'Appius Claudius et le double Forum de Capoue', Latomus 20.4, 683-720. 
Nicolet, C. I984: 'Pline, Paul, et la théorie de la monnaie', Athenaeum 72, I05-35.

North, D. C. 2005: Understanding the Process of Economic Change, Princeton.

Oakley, S. P. I997-2005: A Commentary on Livy, Books VI-X (4 vols), Oxford.

Ogilvie, R. M. I965: A Commentary on Livy Books I-V, Oxford.

Olcese, G. 20I0: Le anfore greco italiche di Ischia: archeologia e archeometria. Artigianato $e$ economia nel Golfo di Napoli, Rome.

Olcese, G., and Coletti, C. (eds) 2016: Ceramica da contesti repubblicani del territorio di Ostia, Rome.

Pais, E. I905: Ancient Legends of Roman History, New York.

Panella, C. 20I0: 'Roma, il suburbio e l'Italia in età medio- e tardo-repubblicana. Cultura materiale, territori, economie', Facta 4, I I-I 23.

Parry, J., and Bloch, M. I989: 'Introduction: money and the morality of exchange', in J. Parry and M. Bloch (eds), Money and the Morality of Exchange, Cambridge, I-32.

Pedroni, L. I993: Ricerche sulla prima monetazione di Roma, Naples.

Pellegrini, E., and Macellari, R. (eds) 2002: I lingotti con il segno del ramo secco. Considerazioni su alcuni aspetti socio-economici nell'area Etrusco-Italica durante il periodo tardo arcaico, Pisa.

Peruzzi, E. I985: Money in Early Rome, Florence.

Piranomonte, M., and Ricci, G. 2009: 'L'edificio rustico di viale Tiziano e la fonte di Anna Perenna. Nuovi dati per la topografia dell'area Flaminia in epoca repubblicana', in Jolivet et al. 2009, 4I3-35.

Prag, J. 2016: 'Antiquae sunt istae leges et mortuae: the plebiscitum Claudianum and associated laws', Mélanges de l'École française de Rome. Antiquité I28.I, http://mefra.revues.org/3202.

Ridley, R. T. I975: 'The enigma of Servius Tullius', Klio 57, I47-77.

Rosenstein, N. 2004: Rome at War: Farms, Families, and Death in the Middle Republic, Chapel Hill.

Rouveret, A., and Theodorescu, D. 2000: 'Recherches à Porta Marina: rapport préliminaire', in E. Greco and F. Longo (eds), Paestum: scavi, studi, ricerche. Bilancio di un decennio (1988I998), Salerno, I9I-6.

Rowan, C. 2013: 'The profits of war and cultural capital: silver and society in Republican Rome', Historia 62.3, 36I-86.

Rowan, C. 20I6: 'Ambiguity, iconology, and entangled objects on coinage of the Republican world', Journal of Roman Studies 106, 2 I-57.

Rutter, N. K. 200I: Historia Numorum, Italy, London.

Saller, R. P. 2005: 'Framing the debate over growth in the ancient economy', in J. G. Manning and I. Morris (eds), The Ancient Economy: Evidence and Models, Stanford, 223-38.

Şaul, M. 2005: 'The circulation of coins and the Roman periphery', Archaeological Dialogues I2.I, $3 \mathrm{I}-4$.

Seaford, R. 2004: Money and the Early Greek Mind: Homer, Philosophy, Tragedy, Cambridge.

Smith, A. I776: An Inquiry into the Nature and Causes of the Wealth of Nations, London.

Smith, C. J. 2007: 'Pliny the Elder and Archaic Rome', in Bispham and Rowe 2007, I47-70.

Smith, C. J. 20I I: 'Thinking about kings', Bulletin of the Institute of Classical Studies 54.2, 2 I-42.

Staveley, E. S. I959: 'The political aims of Appius Claudius Caecus', Historia 8.4, 410-33.

Storchi Marino, A. I993: 'Quinqueviri mensarii. Censo e debiti nel IV secolo', Athenaeum 8I, 2I350.

Tan, J. 20I3: 'Booty and the Roman assembly in 264 B.C.', Historia 62.4, 4I7-I9.

Tan, J. 2017: Power and Public Finance at Rome, 264-49 BCE, Oxford.

Tchernia, A. 2016: The Romans and Trade, Oxford.

Termeer, M. K. 20I6: 'Roman colonial coinages beyond the city-state: a view from the Samnite world', Journal of Ancient History 4.2, I 58-90.

Thomsen, R. I957-6I: Early Roman Coinage (3 vols), Copenhagen.

Thomsen, R. I980: King Servius Tullius, Copenhagen.

Torelli, M. I978: Rerum Romanarum fontes ab anno CCXCII ad annum CCLXV a Ch., Pisa.

Torelli, M. I995: 'Entry into the Senate and ties with the Italian territory of origin: Regio VII (Etruria)', in H. Fracchia and M. Gualtieri (eds), Studies in the Romanization of Italy, Alberta, $44-78$.

Vagi, D. L. 2013: 'Rome's first didrachm in light of the foedus Neapolitanum and the equus October', in P. G. van Alfen and R. B. Witschonke (eds), Essays in Honour of Roberto Russo, New York, 73-93. 
Van der Mersch, C. 200I: 'Aux sources du vin romain dans le Latium et la Campania à l'époque médio-républicaine', Ostraka ıo, I 57-206.

Van Wees, H. 2013: Ships and Silver, Taxes and Tribute: A Fiscal History of Archaic Athens, London.

Verboven, K. 2009: 'Currency, bullion, and accounts: monetary modes in the Roman world', Revue Belge de Numismatique I 55, 9I-I 24.

Vernole, V. E. 2002: Servius Tullius, Rome.

Viglietti, C. 20 I: Il limite del bisogno. Antropologia economica di Roma arcaica, Bologna.

Vitale, R. I999: 'La monetazione romano-campana. Studi e prospettive', Rivista storica del Sannio II, I9-52.

Volpe, R. 2009: 'Vini, vigneti ed anfore in Roma repubblicana', in Jolivet et al. 2009, 369-8I.

Volpe, R. 20I 2: 'Republican villas in the suburbium of Rome', in J. A. Becker and N. Terrenato (eds), Roman Republican Villas: Architecture, Context, and Ideology, Ann Arbor, 94-I Io.

Von Hagen, J. 20I4: 'Microfoundations of the uses of money', in J. von Hagen and M. Welker (eds), The Monetization of the Market and its Impact on Religion, Politics, Law, and Ethics, Cambridge, I9-4I.

Von Reden, S. I995: Exchange in Ancient Greece, London.

Von Reden, S. 20I0: Money in Classical Antiquity, Cambridge.

Wallinga, H. T. I964: 'Nautika (I) the unit capacity for ancient ships', Mnemosyne I7.I, I-40.

Williams, J. H. C. 2007: 'Pliny, antiquarianism, and Roman imperial coinage', in Bispham and Rowe 2007, I7I-82.

Williams, J. H. C., and Burnett, A. M. I998: 'Alexander the Great and the coinages of western Greece', in Ashton and Hurter I998, 379-92.

Woytek, B. 20I4: 'Monetary innovation in ancient Rome: the Republic and its legacy', in P. Bernholz and R. Vaubel (eds), Explaining Monetary and Financial Innovations, London, 197-225.

Zehnacker, H. I979: 'Pline l'ancien et l'histoire de la monnaie romaine', Ktema 4, I69-8I.

Zehnacker, H. I980: 'Unciarium fenus (Tacite, Annales VI, I6)', in Mélanges de littérature et d'épigraphie latines, d'histoire ancienne et d'archéologie. Hommage à la mémoire de Pierre Wuilleumier, Paris, 353-62.

Zelizer, V. I989: 'The social meaning of monies: "special monies", The American Journal of Sociology 95.2, 342-77.

Zevi, F. 2002: 'Appunti per una storia di Ostia repubblicana', Mélanges de l'École française de Rome - Antiquité II4.I, I3-58. 